\title{
Locally Advanced Sarcoma
}

National Cancer Institute

\section{Source}

National Cancer Institute. Locally Advanced Sarcoma. NCI Thesaurus. Code C153071.

Sarcoma that has spread from its original site of growth to nearby tissues or lymph nodes. 